\title{
UČEBNICE ZÁKLADY PROGRAMOVÁNÍ V JAZYCE VISUAL BASIC
}

(KLEMENT, M. Základy programování v jazyce Visual Basic. 1. vyd. Olomouc: Vydavatelství UP Olomouc, 2002. 328 s. ISBN 80-262-4287-9.)

\section{Jan LAVRINČÍK}

Po více než 10 letech od vydání balíku Microsoft Visual Studio 6, je i dnes velmi váženým a používaným nástrojem na poli tvorby desktopových aplikací a aplikací pro správu a ovládání databází typu Oracle a SQL. Program se jeví zhlediska nižší náročnosti z pohledu začínajícího uživatele, cenové dostupnosti pro školy a nízkých hardwarových nárocích jako optimální nástroj pro využití ve výuce programování.

Mezi zcela jedinečné vlastnosti učebnice patří bezesporu způsob vysvětlení ovládání programu a začátky programování na ojedinělých a vhodně tematicky zvolených prŕíkladech. $\mathrm{Na}$ velmi vysoké úrovni je terminologická stránka učebnice s velmi příjemným logickým členěním a přívětivým jazykem z pohledu začínajícího programátora. $\mathrm{V}$ textu jsou vhodně umístěné screeny z prostředí aplikace doplněné o přesné popisky.

Vlastní text skripta je tematicky rozčleněn do čtrnácti kapitol. První kapitola nás v obecné rovině seznamuje s programovacími jazyky. Druhá obsahem větší kapitola nám nastiňuje základní pohled do útrob menu a uživatelského rozhraní. Třetí kapitola nás seznamuje s vývojovým prostředím prostřednictvím př́kladu v podobě naší první mini aplikace. Další kapitoly čtyři až jedenáct jsou demonstrací jednotlivých ovládacích prvků vysvětlených na vhodných př́kladech z prostředí výuky. Jako prríklad můžeme jmenovat aplikace pro „rovnováhu na páce“ nebo „osobní knihovnu“. Kapitola dvanáct nás mimo prríkladu z matematiky učí vytvářet instalátory aplikací. Třináctá kapitola se zmiňuje o výukových programech, jejich taxonomii a se zmínkami o ergonometrii. Čtrnáctá kapitola je soubor zajímavých tipů a triků pro práci s aplikací Visual Basic.

Měkká vazba nenaděluje dílu př́liš dlouhou životnost, ta je ovšem vykompenzována přívětivou cenou $210 \mathrm{Kč}$ za 336 stran textu. Skriptum má uniformovanou polygrafickou úpravu obálky. S ohledem na obsah skripta mu nelze odeprít nadčasovou hodnotu a širokou škálu využití.

K menším nedostatkům uvádím na straně 12 je velmi stručná charakteristika jazyku Assembler a chybí jeho rozdělení, příklady použití a jeho výhody. Dále propojení Netwide Assembler s Visual Basic 6 a príklady. Od strany 12 jsou vynechané ukončovací znaky při použití odrážek. Postrádám náznak alternativního řešení některých zadání vč. ukázky, která by ukazovala, že se nejedná o statický jazyk s jedním správným řešením. $\mathrm{Na}$ straně 22 by v tabulce u datových typů mohl být uveden i znak, který nahrazuje jméno datového typu při deklaraci. $\mathrm{Na}$ stránkách 24 až 26 najdeme dva drobné překlepy (JaZyk a str,) opakující se i na dalších stranách. $Z$ věcných nedostatků bych uvedl možnost o doplnění holých zadání bez řešení pro talentované studenty. Ovládací prvek ListBox by si zasloužil použití alespoň $\mathrm{v}$ jednom z cvičných zadání. Stejný problém vidím s ukázkami možnosti použití „User control“ a zejména potom použití „Resource editoru“, jenž ve výukových aplikacích může najít nespočet uplatnění (obrázky, zvuky, atd.). Pozitivně hodnotím pestrost jednotlivých zadání i jejich přiměřenost $\mathrm{k}$ rozsahu výuky a s ohledem na různorodost složení žáků. Upozornil bych ještě na neaktuální rozdělení výukového software na části I. a II.

Uvedené nedostatky nikterak nesnižují použitelnost a kvalitu učebnice, ale mohou být námětem pro autora $\mathrm{k}$ vydání aktualizovaného a rozšîrreného vydání publikace, jež by si oblast výuky programování zasloužila. Její použití vidím pro edukační účely na středních a vysokých školách, ale i pro počítačové nadšence k rozšíření znalostí z dané oblasti. 